\title{
MENGGAGAS PENDIDIKAN ISLAM HUMANISTIK PERSPEKTIF PEMIKIRAN SYEKH NAWAWI AL-BANTANI
}

\author{
Ahmad Munadirin \\ Sekolah Tinggi Islam Kendal, Indonesia \\ aufahusna.lecture2017@gmail.com
}

\begin{abstract}
Abstraks
Ada beberapa alasan yang melatarbelakangi penelitian pemikiran ini urgen untuk dilaksanakan; pertama, isu-isu pendidikan dehumanisasi, spit personality, dan technocentric yang belum bisa diatasi pendidikan Islam, menjadikan model pendidikan Humanistik yang ideal urgen untuk dicari. Kedua, pencarian model pendidikan Humanistik yang ideal bisa dilakukan dengan mengkaji pemikiran tokoh pendidikan Islam. Ketiga, Syekh Nawawi Al-Bantani merupakan tokoh pendidikan Islam yang berkaliber Internasional. Keempat, ada pemikiran Syekh Nawawi Al-Bantani yang membahas mengenai konsep pendidikan Humanistik. Kelima, belum adanya penelitian mengenai pendidikan Humanistik perspektif pemikiran Syekh Nawawi Al-Bantani. Berdasarkan latar belakang masalah tersebut, maka rekonstruksi pendidikan Islam Humanistik penting untuk direalisasikan. Konstruksi tersebut dilakukan dengan cara menganalisis relevansi empat komponen pendidikan Islam menurut pemikiran Syekh Nawawi dengan konsep pendidikan Islam Humanistik yang ada. Dari hasil konstruksi yang dilakukan, maka tiga komponen pendidikan Islam yang meliputi; hakikat pendidikan dan pengajaran Islam, tujuan pendidikan Islam, dan metode pendidikan Islam menurut Syekh Nawawi relevan dengan konsep pendidikan Islam Humanistik. Adapun pemikiran Syekh Nawawi berkenaan dengan pendidik dan peserta didik, maka konsep ini dinilai kurang relevan dengan konsep pendidikan Islam Humanistik. Dalam hal hakikat pendidikan, tujuan, dan metode pendidikan Islam, antara pemikiran Syekh Nawawi dan konsep pendidikan Humanistik sama-sama mengedepankan aspek kemanusiaan dalam proses pendidikannya. Adapun berkenaan dengan pemikiran Syekh Nawawi mengenai pendidik dan peserta didik dinilai kurang relevan dengan konsep pendidikan Humanistik disebabkan karena syarat pendidik
\end{abstract}


dan peserta didik yang diajukan mengabaikan aspek kemanusiaan pendidikan maupun peserta didik.

Kata kunci: Pendidikan Islam; Humanistik; Pemikiran Syekh Nawawi

There are several reasons behind this research thinking is urgent to implement; first, the issues of dehumanization education, personality spit, and technocentric education that have not been able to be overcome by Islamic education, make the Humanistic education model an urgent need to look for. Second, the search for the ideal model of Humanistic education can be done by examining the thoughts of leaders of Islamic education. Third, Sheikh Nawawi AlBantani is a figure of Islamic education that is of international caliber. Fourth, there is the thought of Sheikh Nawawi Al-Bantani who discussed the concept of Humanistic education. Fifth, there is no research on the perspective of humanistic education in the thinking of Sheikh Nawawi Al-Bantani. Based on the background of the problem, the reconstruction of Humanistic Islamic education is important to be realized. The construction was carried out by analyzing the relevance of the four components of Islamic education according to Syekh Nawawi's thinking with the existing concept of Humanistic Islamic education. From the results of the construction carried out, the three components of Islamic education include; the nature of Islamic education and teaching, the purpose of Islamic education, and the method of Islamic education according to Sheikh Nawawi relevant to the concept of Humanistic Islamic education. The thoughts of Sheikh Nawawi regarding educators and students, this concept is considered less relevant to the concept of Humanistic Islamic education. In terms of the nature of education, the purpose and method of Islamic education, between the thoughts of Sheikh Nawawi and the concept of Humanistic education both put forward humanitarian aspects in the educational process. As for Syekh Nawawi's thoughts on educators and students it is considered less relevant to the concept of Humanistic education because the requirements of educators and students proposed ignore the humanitarian aspects of education and students. 
Keywords: Islamic education; Humanistic; The thoughts of Sheikh Nawawi

\section{A. Pendahuluan}

Perbincangan mengenai pendidikan menjadi senantiasa aktual karena pada hakikatnya manusia yang berfungsi sebagai subyek dan sekaligus obyek pendidikan memiliki sifat multidimensional, tidak terkecuali juga dalam Pendidikan Islam. Perbincangan mengenai Pendidikan Islam mengandung arti perbincangan mengenai manusia itu sendiri. Manusia sebagai makhluk multidimensional senantiasa memiliki dinamika problematika kehidupan.

Problematika kehidupan manusia sebagai pelaku pendidikan saat ini semakin kompleks. Kompleksitas permasalahan manusia ini secara nyata juga menjadi problematika Pendidikan Islam. Problem humanisasi Pendidikan Islam menjadi isu aktual yang selalu dikembangan guna mencari formula yang tepat. Pendidikan Islam Humanistik merupakan salah satu model pendidikan yang dianggap ideal untuk dikembangan saat ini, sehingga Pendidikan Islam mampu memberikan sumbangsih nyata bagi problematika yang ada di tengah masyarakat.

Meminjam istilah Immanuel Kant yang menyatakan bahwa "manusia hanya akan menjadi manusia karena pendidikan"1, maka model Pendidikan Islam yang ideal sangat urgen untuk dikaji dan dicari tanpa mengenal batas ruang dan waktu.

\footnotetext{
${ }^{1}$ Eko Susilo, Dasar-Dasar Pendidikan, cet. 3, (Semarang: Effhar, 2001), 19.
} 
Problematika Pendidikan Islam dinamis dan senantiasa berkembang, untuk itu model Pendidikan Islam yang dijalankan juga harus menyesuaikan dan senantiasa dikembangkan juga supaya dinamis.

Perkembangan globalisasi dan modernisasi yang terus melejit saat ini mampu menerobos ruang dan waktu, sehingga hal ini menimbulkan high risks bagi perkembangan akhlak dan moral peserta didik. Saat ini melalui model Pendidikan Islam Humanistik, peserta didik disajikan nilai-nilai karakter di sekolah, akan tetapi ketika keluar dari sekolah para peserta didik dengan mudah menemui ralitas dekandensi moral yang semakin nyata. Hal inilah yang menyebabkan peserta didik sering mengalami split personality.

Paulo Friere dalam bukunya yang berjudul "pendidikan kaum tertindas" memaparkan bahwa pendidikan justru menjadi perangkat dehumanisasi. ${ }^{2}$ Praktek ini seringkali ditemui karena adanya faktor kepentingan dari pemangku kebijakan pendidikan. Nilai humanisme pendidikan menjadi kabur ketika memang berbenturan dengan factor of interest.

Paulo Friere menambahkan bahwa pola pendidikan dehumanisasi dalam prakteknya mengedepankan pola pendidikan gaya bank, artinya pendidikan dimaknai sebagai proses transfer ilmu pengetahuan dari orang yang memiliki banyak pengetahuan kepada orang yang dianggap tidak memiliki pengetahuan.

2 Paulo Friere, Pendidikan Kaum Tertindas (Jakarta: LP3ES, 1991), 26. 
Education is transfer a certain knowledge from teachers to their students. ${ }^{3}$ Dalam pengertian lain pratik pendidikan yang demikian ini diartikan bahwa pendidikan adalah memindahkan ilmu dari otak (yang satu) ke otak (yang lain).

Praktik dehumanisasi pendidikan ini masih sangat sering terjadi dalam dunia pendidikan, termasuk juga dalam Pendidikan Islam. Persepsi pendidik yang menganggap peserta didik seperti gelas kosong yang harus diisi air menyebabkan peserta didik diposisikan secara pasif. Guru sebagai sumber air mendominasi proses pembelajaran. Aspek kemanusiaan dalam model pendidikan seperti ini sangat dikaburkan. Ironisnya, praktik pendidikan seperti ini masih sangat sering dijumpai dalam pendidikan.

Isu technocentric yang saat ini melanda manusia membuat aspek kemanusian humancentric menjadi semakin kabur. Dunia ini sekarang menjadi global village, artinya dunia yang sangat luas menjadi seperti sangat sempit seperti desa. Jarak JakartaWashington misalnya, sekarang seperti jarak Jakarta-Bandung secara riil. Hal ini karena kemajuan teknologi yang pesat sehinga menggeser humancentric yang harusnya berlaku menjadi technocentric. ${ }^{4}$

Isu dehumanisasi, spit personality, dan technocentric agaknya sudah cukup membuat pengembangan model Pendidikan

\footnotetext{
3 Paulo Friere, Pendidikan Kaum Tertindas (Jakarta: LP3ES, 1991), 51.

4 Mudjia Rahardjo, "Menuju Pendidikan Humanistik yang Berwawasan Pembangunan", Majalah Tarbiyah No. 35, (Tahun XII, Juli-September 1994), 18.
} 
Islam Humanistik terus dilakukan. Salah satu cara mengembangkan model Pendidikan Islam Humanistik yaitu menggunakan pendekatan sosio-historis dengan melakukan pengkajian terhadap pemikiran para pakar Pendidikan Islam terdahulu.

Syekh Nawawi Al-Bantani merupakan salah satu tokoh atau pakar Pendidikan Islam kelas internasional yang layak untuk dikaji. Tokoh caliber internasional ini berasal dari Indonesia. Syekh Nawawi banyak menuangkan ide dan pemikirannya mengenai Pendidikan Islam. Pendidikan Islam Humanistik yang menjadi isu aktual saat ini juga memiliki relevansi dengan pemikiran Syekh Nawawi.

Ketokohan Syekh Nawawi sebagai tokoh berkaliber internasioanal dibuktikan dengan prestasinya menjadi maha guru ulama Internasional. Syekh Nawawi sebenarnya memiliki banyak pemikiran di bidang Pendidikan Islam, hanya saja belum tersusun secara sistematis. Untuk itu, perlu sebuah upaya konstruksi pemikiran Pendidikan Islam yang utuh dan sistematis. ${ }^{5}$

Pemikiran Syekh Nawawi dalam Pendidikan Islam antara lain meliputi pemikiran mengenai hakikat pendidikan dan pengajaran Islam, sumber pendidikan Islam, tujuan pendidikan Islam, metode pendidikan Islam, serta pendidik dan peserta didik dalam Pendidikan Islam. Pemikiran mengenai konsep Pendidikan

\footnotetext{
5 Maragustam, Pemikiran Pendidikan Syekh Nawawi Al-Bantani, (Yogyakarta: Datamedia, 2007), 1.
} 
Islam tersebut urgen untuk dikaji guna menemukan relevansi pemikiran Syekh Nawawi dengan Pendidikan Islam Humanistik yang saat ini terus dikembangkan dalam rangka menemukan model yang ideal.

Secara konseptual, sebenarnya Syekh Nawawi dalam pemikirannya sudah mengandung konstruksi Pendidikan Islam Humanistik, meskipun memang belum dikonstruksikan secara sistematis. Relevansi yang sudah ditemukan, kemudian direkonstruksi ulang secara sistematis, sehingga konstruksi Pendidikan Islam Humanistik dalam pemikiran Syekh Nawawi Al-Bantani ini berhasil terealisasi.

Berdasarkan pemaparan diatas, maka ada beberapa alasan yang melatarbelakangi penelitian pemikiran ini urgen untuk dilaksanakan; pertama, isu-isu pendidikan dehumanisasi, spit personality, dan technocentric yang belum bisa diatasi pendidikan Islam, menjadikan model pendidikan Humanistik yang ideal urgen untuk dicari. Kedua, pencarian model pendidikan Humanistik yang ideal bisa dilakukan dengan mengkaji pemikiran tokoh pendidikan Islam. Ketiga, Syekh Nawawi AlBantani merupakan tokoh pendidikan Islam yang berkaliber Internasional. Keempat, ada pemikiran Syekh Nawawi Al-Bantani yang membahas mengenai konsep pendidikan Humanistik. Kelima, belum adanya penelitian mengenai pendidikan Humanistik perspektif pemikiran Syekh Nawawi Al-Bantani. 
Selanjutnya, berdasarkan latar belakang masalah diatas, guna melakukan rekonstruksi Pendidikan Islam Humanistik dalam pemikiran Syekh Nawawi Al-Bantani, maka ada beberapa hal yang penting untuk dikaji, yaitu; pertama, pemikiran Pendidikan Islam Syekh Nawawi Al-Bantani. Kedua, konsep Pendidikan Islam Humanistik. Ketiga, konstruksi Pendidikan Islam Humanistik dalam pemikiran Syekh Nawawi Al-Bantani.

Pendekatan yang digunakan dalam mengkaji pemikiran Syekh Nawawi ini menggunakan pendekatan sosio-historis, artinya mengkajian dilakukan terhadap sejarah pemikiran Syekh Nawawi. Adapun analisis penelitian literer ini menggunakan analisis kualitatif kritis, artinya mendeskripsikan pemikiran Syekh Nawawi yang kemudian dianalisis relevansinya dengan model Pendidikan Islam Humanistik.

\section{B. Konsepsi Pendidikan Humanistik}

\section{Urgensi Pendidikan Humanistik}

Technocentric menjadi isu yang saat ini sedang menjangkiti dunia pendidikan Indonesia. Pendidikan saat ini sudah bergeser dari humancentric atau yang berpusat pada manusia mengarah kepada pendidikan yang berpusat pada teknologi.

\section{Pengertian Pendidikan Humanistik}

Carlo Nanni memaparkan pendidikan sebagai pengembangan kemampuan fundamental pribadi seseorang untuk mengahayati kehidupan di dunia secara bebas dan 
bertanggung jawab, baik dalam kebersamaan dengan orang lain, dalam persimpangan relasi interpersonal, dan dalam kehidupan sosial yang tertata dan terorganisasi secara historis. ${ }^{6}$ Selanjutnya, Horne menyebutkan pendidikan sebagai proses yang terus menerus dari penyesesuaian yang lebih tinggi bagi manusia yang telah berkembang secara fisik dan mental, yang bebas dan sadar kepada Tuhan, seperti termanifestasi dalam alam sekitar intelektual, emosional dan kemanusiaan. ${ }^{7}$ Selain itu, dengan lebih menekankan aspek kebudayaan, Ki Hajar Dewantara mendefinisikan pendidikan sebagai usaha kebudayaan yang bermaksud memberi bimbingan dalam hidup tumbuhnya jiwa raga anak supaya dalam kodrat pribadi dan lingkungannya mendapatkan kemajuan lahir batin menuju ke arah adab kemanusiaan. Ki Hajar Dewantara mendefinisikan adab kemanusiaan sebagai tingkatan tertinggi yang dapat dicapai oleh menusia yang berkembang selama hidupnya. 8

Ali Saifullah dengan menggunakan pendekatan filsafat mendefinisikan bahwa pendidikan merupakan upaya untuk menanamkan nilai-nilai dan norma-norma tertentu sebagaimana yang telah ditetapkan dalam kajian filsafat

\footnotetext{
${ }^{6}$ Carlo Nanni, Dizionairo di Scienze dell'Educazione, (Torlino: Pada Lema Educazione, Elle di CI, L.A.S dan S.E.I, 1997), hlm. 340, dikutip dalam Donnie Kosoema A, Pendidikan Karakter, (Jakarta: Grasindo, 2007), hlm. 63.

${ }^{7}$ Ngalim Purwanto, Ilmu Pendidikan Teoritis dan Praktis, (Jakarta: Grasindo: 1985), hlm. 28-29.

${ }^{8}$ Ki Suratman, Pokok-Pokok Ketamansiswaan, (Yogyakarta: Majelis Luhur Persatuan Taman Siswa, 1987), hlm. 12.
} 
pendidikan yakni nilai atau norma yang dijunjung tinggi oleh suatu lembaga pendidikan. ${ }^{9}$ Selanjutnya, Hasan Langgulung mendefinisikan pendidikan sebagai proses spiritual, akhlak, intelektual, dan sosial yang berusaha membimbing manusia dan memberinya nilai-nilai, prinsip-prinsip, dan teladan ideal dalam kehidupan yang bertujuan mempersiapkan kehidupan dunia ahirat. ${ }^{10}$ Zakiyah Darajat mendefinisikan pendidikan secara singkat yaitu pembentukan kepribadian. ${ }^{11}$

Dengan lebih menekankan aspek humanisasi, H.A.R Tilaar mendefinisikan pendidikan sebagai upaya untuk memanusiakan manusia. Lebih lanjut Tilaar menjelaskan bahwa pendidikan merupakan proses yang berkesinambungan yang berfungsi untuk mengembangkan eksistensi manusia dalam kehidupan bermasyarakat dan bersosial. ${ }^{12}$ Sementara itu, dalam UU Sisdiknas Nomor 20 Tahun 2003 dijelaskan bahwa pendidikan sebagai usaha sadar dan terencana untuk mewujudkan suasana belajar dan proses pembelajaran agar peserta didik secara aktif mengembangkan potensi diri, kepribadian, kecerdasan, akhlak mulia, serta ketrampilan yang diperlukan dirinya, masyarakat, bangsa dan negara. ${ }^{13}$

\footnotetext{
9 Ali Saifullah, Pendidikan, Pengajaran, dan Kebudayaan Pendidikan Sebagai Gejala Pendidikan, (Surabaya: Usaha Nasional, 1982), hlm. 53-54.

${ }^{10}$ Hasan Langgulung, Asas-Asas Pendidikan Islam, (Jakarta: Pustaka AlHusna, 1993), hlm. 62.

${ }^{11}$ Zakiyah Darajat, Ilmu Pendidikan Islam, (Jakarta: Bumi Aksara, 2006), hlm. 28.

12 H.A.R Tilaar, Education, Culture, and The Indonesian Civil Society: Indonesian Education Reform Policies for The Third Millenium, (Bandung: Rosdakarya, 1999), hlm. 3.

${ }^{13}$ Undang-Undang Sistem Pendidikan Nasional Nomor 20 Tahun 2003.
} 
Menggagas Pendidikan Islam Humanistik Perspektif Pemikiran Syekh Nawawi Al-Bantani 


\section{Pemikiran Pendidikan Islam Syekh Nawawi Al-Bantani}

Sebelum mengkaji secara mendalam mengenai pemikiran Pendidikan Islam Syekh Nawawi Al-Bantani, maka perlu rasanya mengetahui biografi Syekh Nawawi Al-Bantani.

\section{Biografi Syekh Nawawi Al-Bantani}

Nama lengkap Syekh Nawawi Al-Bantani adalah Abu Abdul Mu'ti Muhammad bin Umar bin Arbi bin Ali Al-Tantara Al-Jawi Al-Bantani. Nama populernya yaitu Muhammad Nawawi Al-Jawi Al-Bantani. ${ }^{14}$ Syekh Nawawi lahir di kampung Tanara, Tirtayasa, Serang, Banten pada tahun $1813 \mathrm{M}$ atau 1230 H. Syekh Nawawi wafat di Ma'la Mekah Saudi Arabia pada tahun 1897 M bertepatan dengan tanggal 25 Syawwal $1314 \mathrm{H}$ dalam usia 84 tahun. $^{15}$

Menurut pelacakan geneologi, Syekh Nawawi adalah keturunan yang ke 12 dari Maulana Syarif Hidayatullah (Sunan Gunung Jati Cirebon), yaitu keturunan dari putera Maulana Hasanuddin (Sultan Banten I) yang bernama Sunyararas (Tajul 'Arsy). ${ }^{16}$ Syekh Nawawi merupakan keturunan dari ulama besar di tanah Jawa yang sangat berjasa mengislamkan Jawa.

Silsilah keturunan Syekh Nawawi sampai kepada Nabi Muhammad SAW jika dilihat dari silsilah ayahnya. Silsilah keturunan Syekh Nawawi dari ayahnya adalah Nawawi bin

14 Muhammad Ulul Fahmi, Ulama Besar Indonesia Biografi dan Karyanya, (Kendal: Amanah Grafika, 2008), hlm. 4.

${ }^{15}$ Maragustam, Pemikiran Pendidikan..., hlm. 100.

${ }^{16}$ Maragustam, Pemikiran Pendidikan..., hlm. 100. 
kiai Umar bin Kiai Arabi bin Kiai Ali bin Kiai Jamad bin Janta bin Kiai Masbugil bin Kiai Tajul 'Arsy Tanara bin Maulana Hasanuddin Banten bin Maulana Syarif Hidayatullah Cirebon bin Maulana Jamaluddin Akbar Husain bin Imam Sayyid Ahmad Syah Jalal bin Abdullah Adzmah Khan bin Amir Abdullah Malik bin Sayyid Ali Khali' Qasim bin Sayyid Alwi bin Imam Ubaidillah bin Imam Ahmad Muhajir Ilallahi bin Imam Isa an-Naqib bin Imam Muhammad Naqib bin Imam Ali Aridhi bin Imam Ja'far ash-Shadiq bin Imam Muhammad alBaqir bin Imam Ali Zainal Abidin bin Sayyidina Husain bin Sayyidatuna Fathimah Zahra binti Muhammad Rasulullah SAW. Adapun dari silsilah dari ibunya adalah bahwa Nawawi putera Nyai Zubaidah binti Muhammad Singaraja. ${ }^{17}$

Beliau adalah ulama' yang ahli di bidang tafsir, tauhid, fiqh, tasawuf, sejarah nabi, bahasa dan retorika, karya-karya beliau memberikan sumbangan yang sangat besar dalam kemajuan islam di Indonesia, banyak sekali ulama' dan pejuang-pejuang islam yang berguru pada beliau, karena itulah jasa beliau sangat besar dalam mengislamkan Indonesia.

Nama Syekh Nawawi Al-Bantani sudah tidak asing lagi di kalangan umat Islam Indonesia. Bahkan kebanyakan orangorang menjulukinya sebagai Imam Nawawi kedua. Melalui karya-karyanya yang tersebar di pesantren-pesantren

17 Sudirman Tebba, Mengenalkan Wajah Islam Yang Ramah (Banten: Pustaka Irvan, 2007), hlm. 156. 
tradisional yang sampai sekarang masih banyak dikaji, nama kyai asal Banten ini seakan-akan masih hidup dan terus menyertai umat memberi wejangan ajaran Islam yang menyejukkan. Di setiap majlis ta'lim karyanya selalu dijadikan rujukan utama dalam berbagai ilmu, dari ilmu tauhid, fiqih, tasawuf sampai tafsir. Dikalangan komunitas pesantren Syekh Nawawi tidak hanya dikenal sebagai penulis kitab, akan tetapi sebagai mahaguru sejati (The Great Scholar).

Syekh Nawawi telah banyak berjasa meletakkan landasan theologis dan batasan-batasan etis tradisi keilmuan di lembaga pendidikan pesantren. Ia turut banyak membentuk keintelektualan tokoh-tokoh para pendiri pesantren. ${ }^{18}$ Diungkapkan oleh Azumardi Azra yang dikutip oleh Maragustam bahwa Syekh Nawawi sebagai ulama yang tidak saja mumpuni dalam bidangnya, tapi juga disegani baik dikalangan dunia intelektualisme Indonesia maupun di kalangan dunia Timur Tengah dan Internasional umumnya.

Syekh Nawawi mempunyai tiga posisi utama yang membuat namanya diperhitungkan banyak kalangan. Pertama, sebagai ulama yang sangat produktif dalam menulis dan mempunyai banyak karya, bahkan ada yang bilang sampai ratusan judulnya bukunya. Kedua, Syekh Nawawi merupakan salah satu pusat jaringan ulama dan pesantren. Ini dapat dilihat dari sejarahnya dia belajar di Mekkah kemudian tidak sedikit

18 Muhammad Ulul fahmi, Ulama Besar Indonesia..., hlm. 9-10. 
orang yang berguru kepadanya, termasuh K.H. Hasyim Asy'ari dan beberapa ulama ternama di Madura. Di sinilah dia menjadi semacam puncak dari sumber tradisi pesantren. Ketiga, Syekh Nawawi adalah ulama jawi yang bermukim di Mekah dan mendapatkan banyak ilmu serta pengakuan dari dunia internasional. ${ }^{19}$

\section{Pemikiran Pendidikan Islam}

Pemikiran Pendidikan Islam Syekh Nawawi Al-Bantani meliputi hal-hal sebagai berikut;

a. Hakikat Pendidikan dan Pengajaran dalam Islam

Secara konseptual Pendidikan Islam diartikan sebagai usaha sadar yang dilakukan untuk mencapai tujuan Pendidikan Islam, baik secara formal, informal, maupun nonformal. Pendidikan Islam bertujuan agar siswa memiliki ilmu pengetahun dan ketrampilan dalam rangka berbuat baik sesama manusia, beribadah kepada Allah, dan semakin dekat dengan Allah, disamping itu siswa diharapkan tidak hanya belajar nilai-nilai moral saja, akan tetapi dapat memberikan makna nilai-nilai tersebut dalam kehidupan sehari-hari yang Islami. ${ }^{20}$

Guna menemukan hakikat pendidikan dan pengajaran dalam Pendidikan Islam, maka pengkajian mengenai makna ta'lim, tarbiyah, dan $t a^{\prime} d i b$ perlu dilakukan. Berkaitan dengan

${ }_{19}$ Maragustam, Pemikiran Pendidikan..., hlm. 7-8.

20 Imam Machali, Pendidikan Islam \& Tantangan Globalisasi (Yogyakarta: Ar-Ruzz Media, 2004), hlm. 26-27. 
makna ketiga kata ini, maka sampai saat ini masih terjadi perbedaan dan belum ada kesepakatan secara pasti dari para ahli Pendidikan Islam. Perbedaan tersebut pada prinsipnya karena perbedaan pendekatan yang digunakan, ada yang menggunakan pendekatan bahasa, pendekatan konteks kedudukan kata dalam rangkaian kalimat-kalimat AlQur'an dan Hadits, dan ada pula yang melakukan pemilihan ayat atau Hadits lain yang bisa menjelaskan kata ta'lim, tarbiyah dan $t a^{\prime} d i b .{ }^{21}$

Makna kata $t a^{\prime} l i m$, tarbiyah dan $t a^{\prime} d i b$ menurut pemikiran Syekh Nawawi Al-Bantani terdapat dalam penafsiran terhadap ayat-ayat sebagai berikut; QS. AlBaqarah: 129 dan 151, QS. Al-Jumu'ah: 2, dan QS. Ali Imran:

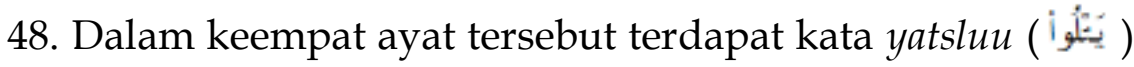

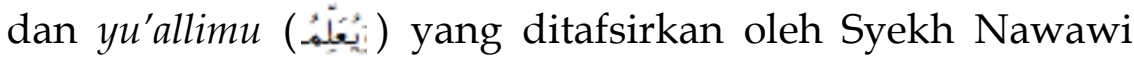
bahwa yatsluu yang artinya membacakan dalam ayat ini bukan hanya sebatas membacakan saja, akan tetapi membacakan dengan mengarahkan manusia kepada iman, sedangkan kata yu'allimu yang bermakna mengajarkan, Syekh Nawawi memberikan makna yang lebih luas, yaitu mengajarkan dan memahamkan nilai-nilai dari ajaran tersebut serta bagaimana mengimplementasikan ajaran tersebut dalam kehidupan sehari-hari.

${ }^{21}$ Maragustam, Pemikiran Pendidikan..., hlm. 200. 
Syekh Nawawi bahwa proses ta'lim dalam Islam mencakup transfer (pemindahan) ilmu, nilai dan metode dan trasformasi (hal-hal yang diterima peserta didik itu menjadi miliknya dan dapat merubah serta membentuk pribadinya). Karena dalam mengajarkan tilawah Al-Qur'an dan Sunnah tidak terbatas pada bahwa nabi Muhammad SAW menyuruh umatnya untuk sekedar membaca AlQur'an, akan tetapi juga mengajari mereka kandungannya yakni perintah dan larangan, mengimani kebenarannya dan mengingatkannya dengan menunjukkan berbagai buktibukti kebesaran Allah SWT. Cara membaca seperti ini tentu tidak sekedar dapat membaca Al-Quran dengan tajwid, melainkan membaca dengan perenungan dan berisikan pemahaman, pengertian, tanggung jawab dan penanaman amanah. $^{22}$

Berkenaan dengan makna tarbiyah, maka Syekh Nawawi Al-Bantani menafsirkan QS. Al-Isra': 24. Kata tarbiyah lebih ditekankan kepada pendidikan anak diwaktu kecil dalam ayat ini. Syekh Nawawi menafsirkan bahwa kita wajib berbuat baik kepada kedua orang tua kita dan juga mendoakannya walaupun hanya lima kali dalam

22 Syekh Muhammad Nawawi, Murah Labayd (Mesir: Darul Ihya'Al-Kutb Al'Arabiyah, Tanpa Tahun), hlm. 35. 
sehari, karena kedua orang tua kitalah yang telah mendidik kita dari kecil hingga dewasa. ${ }^{23}$

Berkenaan dengan makna $t a^{\prime} d i b$, Maragustam sebagaimana yang dikutib dari Syarh 'Uqud karangan Syekh Nawawi, menegaskan bahwa Syekh Nawawi mengartikan makna $t a^{\prime} d i b$ disamakan dengan ta'lim, akan tetapi $t a^{\prime} d i b$ lebih ditekankan kepada pembentukan Akhlak. Dengan demikian, Syekh Nawawi tidak terlalu membedakan antara makna $t a^{\prime} l i m$ dan $t a^{\prime} d i b$, karena semuanya mengacu kepada trasformasi dalam pendidikan. ${ }^{24}$

b. Tujuan Pendidikan Islam

Pada hakikatnya tujuan pendidikan Islam adalah idealitas yang mengandung nilai-nilai Islami yang akan dicapai melalui proses pendidikan yang berdasarkan ajaran Islam secara bertahap. Tujuan Pendidikan Islam ini juga senada dengan Arifin yang menyampaikan bahwa tujuan Pendidikan Islam merupakan penggambaran nilai-nilai Islami yang akan diwujudkan dalam pribadi peserta didik dalam sebuah proses sebuah pendidikan.

Hal yang sama juga disampaikan oleh Athiyah yang memaparkan bahwa tjuan Pendidikan Islam bukanlah sebatas memenuhi otak peserta didik dengan segala macam ilmu yang belum mereka ketahui, melainkan: a) Mendidik

23 Syekh Muhammad Nawawi, Murah labayd..., hlm. 376.

${ }^{24}$ Maragustam, Pemikiran Pendidikan..., hlm. 206-207. 
akhlak dan jiwa anak; b) Menanamkan rasa keutamaan; c) Membiasakan mereka dengan kesopanan yang tinggi; dan d) Mempersiapkan mereka untuk suatu kehidupan dengan penuh keihklasan dan kejujuran. ${ }^{25}$

Syekh Nawawi menentukan tujuan pendidikan Islam dengan mengambil penjelasan tentang tujuan peserta didik menuntut ilmu dan juga fungsi manusia di bumi sebagai khalifah yang tugasnya beribadah kepada Allah yang mana itu semuanya tertulis dalam QS. Adz-Dzariyat: 56, QS. AlBaqarah: 21, QS. Al-Anbiya: 25, dan QS. An-Nahl: 36.

Berdasarkan ayat-ayat tersebut, Syekh Nawawi berpendapat bahwa tujuan Pendidikan Islam merupakan sebuah refleksi dari fungsi manusia untuk beribadah kepada Allah SWT dan menjadi khalifah di muka bumi. Secara lebih rinci Syekh Nawawi mengklasifikasikannya sebagai berikut; 1) Pendidikan Islam agar memperoleh ridho dari Allah dan memperoleh kehidupan di akhirat; 2) Pendidikan Islam berguna untuk menyingkirkan kebodohan dari dalam diri manusia, dan mengajarkan apa yang sudah dia pelajari kepada orang lain agar kebodohan itu lenyap; 3) Pendidikan Islam untuk menghidupkan agama dan mengabadikan Islam dengan sinaran ilmu; dan 4) Pendidikan Islam untuk

25 Muhammad 'Atthiyyah AL-Abrasyi, Prinsip-prinsip dasar Pendidikan Islam (Bandung: Pustaka Setia, 2003), hlm.13. 
mensyukuri nikmat Allah SWT berupa akal dan badan yang sehat. $^{26}$

c. Metode Pendidikan Islam

Pada prinsipnya, metode Pendidikan Islam sangat efektif dalam membina kepribadian peserta didik dan memotivasi mereka sehingga nilai keislaman dapat teraplikasikan dalam dunia pendidikan secara meluas.

Dalam hal ini Nahlawi menklasifikasikan beberapa metode yang relevan dikembangkan di dalam Pendidikan Islam yaitu: a) Metode dialog Qur'ani dan Nabawi; b) Mendidik melalu kisah-kisah Qur'ani dan Nabawi; c) Mendidik melalui perumpamaan Qur'ani dan Nabawi; d) Mendidik melalui keteladanan; e) Mendidik melalui aplikasi dan pengalaman; f) Mendidik melalui ibrah dan nasehat; g) Mendidik melalui targhib dan tarhib. ${ }^{27}$

Hal yang berbeda diungkapkan oleh 'Athiyyah yang mengutip pendapat Imam Ghozali dan Ibnu Kholdun. Menurut Imam Ghozali metode pengajaran yang dipergunakan dalam mengajar anak-anak harus berbeda dengan metode yang digunakan untuk mengajar orangorang besar. Imam Ghozali berkata:

${ }^{26}$ Maragustam, Pemikiran Pendidikan..., hlm. 210-211.

27 Kata Targhib diambil dari kata kerja raghaba yang berarti menyenangi, menyukai dan mencintai. Kemudian diubah menjadi kata benda targhib yang mengandung makna suatu harapan untuk memperoleh kesenangan, kecintaan, kebahagiaan. Sedangkan kata Tarhib berasal dari kata rahhaba yang berarti menakut-nakuti atau mengancam, lalu dirubah menjadi kata benda yaitu tarhib yang berarti ancaman atau hukuman. 
"Kewajiban utama dari seorang pendidik ialah mengajarkan kepada anak-anak setiap masalah yang mudah dan dapat difahaminya. Karena masalahmasalah yang pelik justru akan mengakibatkan kerancuan pikiran dan menyebabkan ia melarikan diri dari ilmu"

Hal senada juga diungkapkan oleh Ibnu Kholdun yang mengatakan bahwa;

“Banyak kita lihat dewasa ini ini para pengajar yang tidak mengerti cara mengajar dan memanfaatkan pelajaran, pada permulaan saja, mereka telah memberikan masalah-masalah yang sulit kepada para murid dan memintanya untuk memecahkan masalah tersebut, dan mereka anggap cara itulah yang sebaikbaiknya untuk melatih anak-anak dan cara itulah yang benar. Padahal sesungguhnya kemauan dan kesediaan adalah sesuatu yang datang secara berangsur." 28

Dalam masalah ini Syekh Nawawi mempunyai pendapat tidak jauh berbeda dari pendapat Imam Ghozali dan juga Ibnu Ibnu Kholdun, akan tetapi pemikiran Syekh Nawawi lebih mendalam, berikut adalah pemikiran Syekh Nawawi tentang prinsip dan metode pendidikan Islam: 1) Dalam menyajikan mata pelajaran dimulai dari yang paling mudah, yang konkrit, yang dapat ditangkap oleh akal pikiran peserta didik, baru kemudian bertahap dibawa kepada yang lebih sulit, abstrak dan komplek. Mendekatkan materi pengetahuan yang diajarkan dengan pemahaman peserta didik seiring dengan perkembangan usianya, tingkat

28 Muhammad 'Atthiyyah Al-Abrasyi, Prinsip-prinsip dasar Pendidikan Islam..., hlm. 25. 
kematangan bahasa dan inteleknya; 2) Prinsip mengetahui keadaan peserta didik, seperti kematangan dan perbedaan individual dan lain sebagainya; 3) Prinsip menggunakan metode mengajar yang berbeda sesuai dengan tingkat kemampuan watak peserta didik; 4) Prinsip pengajaran sebagai pengalaman yang menggembirakan; 5) Prinsip pengajaran sebagai pengalaman yang memberi kebebasan berfikir sehingga pendidik tidak perlu mendominasi percakapan; 6) Prinsip partisipasi aktif atau pengalaman langsung tentang materi yang disampaikan. Dengan kata lain pendidik adalah barisan terdepan dalam pengamalan apa yang akan diajarkannya; 7) Prinsip memberikan penjelasan mata pelajaran dengan penjelasan yang mudah dimengerti; dan 8) Prinsip pengulangan terkait pelajaran yang sudah pelajari. ${ }^{29}$

Dari pendapat di atas dapat diambil kesimpulan bahwa sebenarnya pendapat Syekh Nawawi tidak begitu berbeda dengan pendapat dari ulama lain terkait prinsipprinsip metode Pendidikan Islam, bahkan pendapat yang dikemukan oleh Syekh Nawawi jauh lebih luas penjelasannya. Sehingga secara umum pendapat yang diungkapkan oleh Syekh Nawawi tetap dapat kita aplikasikan dalam pendidikan Islam, terutama di sekolah yang berbasis tradisional seperti pesantren salaf. Adapun

${ }^{29}$ Maragustam, Pemikiran Pendidikan Syekh Nawawi Al-Bantani..., hlm. 222-223. 
ketika akan diaplikasikan dalam pesantren khalaf dengan system pendidikan formalnya, maka perlu dilakukan penyesuaian.

d. Pendidik dan Peserta Didik

Berhubungan dengan pentingnya pendidik dalam perkembangan peserta didik, maka syekh Nawawi memberikan etika ketat bagi para pendidik yaitu; 1) Tabah dan sabar menerima segala persoalan yang dihadapkan peserta didik; 2) Senantiasa bermurah hati dalam berbagai hal; 3) Duduk berwibawa dengan cara terhormat sambil menundukkan kepala dan melonggarkan pandangan; 4) Tidak sombong kepada sesama manusia, kecuali kepada orang yang terang-terangan dzalim sebagai peringatan larangan atas kedzalimannya.

Berbuat sombong kepada orang yang sombong itu adalah sedekah sebagaimana tawadhu kepada orang yang tawadhu; 5) Bersikap tawadhu dalam pertemuan-pertemuan dalam majelis; 6) Menghindari bercanda dan senda gurau; 7) Bersikap lemah lembut dan ramah tamah kepada peserta didik ketika mengajar dan sabar dalam menghadapi orang yang pandai mengungkapkan pertanyaan; 8) Mendidik anak yang tidak cerdas (idiot) dengan pengajaran yang baik; 9) Tidak marah-marah (membentak-bentak) dan tidak pula menyindir peserta didik yang bodoh dalam proses 
pengajarannya, tetapi dengan pengajaran yang baik; 10) Tidak merasa segan dan malu untuk berkata "saya tidah tahu" atau "Allah yang maha tau" jika suatau masalah belum dikuasainya atau belum belum diketahuinya;

Selanjutnya 11) Menyimak orang yang bertanya dan memahami pertanyaannya supaya dijawab dengan baik; 12) Dapat menerima argumen atau dalil dari orang lain dan menyimaknya walaupun argumentasi itu berasal dari yang bukan sefaham dengannya. Karena mengikuti kebenaran itu wajib; 13) Tunduk kepada kebenaran, dan kembali kepada kebenaran ketika melakukan kesalahan dalam berbicara atau memegang keyakinan, walaupun yang benar itu berasal dari orang yang lebih rendah derajatnya daripada pendidik sendiri; 14) Mencegah peserta didik dari setiap ilmu yang membahayaknnya dalam hal agama seperti ilmu sihir, ilmu nujum (perbintangan) dan astrologi;

Selanjutnya 15) Mencegah peserta didik belajar dan menggunakan ilmu yang bermanfaat demi selain mencari ridho Allah dan negeri akherat; 16) Mencegah peserta didik dari kesibukan kewajiban komunal sebelum menyelesaikan kewajiban personal yaitu memperbaiki lahir dan batinnya dengan takwa yakni melaksanakan ibadah lahir dan batin serta menjauhi maksiat lahir batin; 17) Menginstrospeksi diri sendiri terlebih dahulu, sebelum memerintahkan orang lain mengerjakan kebaikan, dan sebelum melarang orang lain 
berbuat kejahatan dengan menjunjung tinggi perintah agama dan menjauhi larangannya, agar peserta didik dapat mengambil teladan dari perbuatan-perbuatannya dan mengambil manfaat dari ucapan-ucapannya. ${ }^{30}$

Ada tujuh belas kriteria yang disyaratkan oleh Syekh Nawawi berkaitan dengan pendidik. Adapun berkenaan dengan peserta didik, maka Syekh Nawawi memaparkan bahwa peserta didik harus memiliki sifat hormat terhadap pendidik sebagai syarat meperoleh ilmu. Berkaitan dengan peserta didik, syekh Nawawi memberikan beberapa empat belas etika yang harus dikerjakan oleh para peserta didik dalam menghadapi pendidik dalam proses belajar mengajar yaitu;

a) Lebih dulu memulai penghormatan, salam dan meminta ijin ketika memasuki majelis taklim; b) Mempersedikit bicara dan mempersedikit sesuatu yang diperbolehkan ketika berada dihadapan gurunya; c) Tidak mengatakan/berbicara hal yang tidak ditanyakan; d) Tidak bertanya tentang sesutu sebelum meminta ijin terlebih dahulu atau tidak bertanya sebelum ada persoalan; e) Tidak mengkontradiksikan pendapat gurunya dengan pendapat orang seperti misalanya "si fulan berbeda dengan pendapat anda atau yang semacamnya";

${ }^{30}$ Maragustam, Pemikiran Pendidikan Syekh Nawawi Al-Bantani..., hlm. 228-229. 
Selanjutnya f) Tidak menunjukkan pendapat yang berbeda dengan pendapat gurunya, karena anggapan peserta didik bahwa dirinya lebih mengetahui kebenaran dalam masalah itu. Sikap demikian akan mengurangi sopan santun dan mengurangi berkah ilmunya; g) Jangan bertanya ke teman gurumu di tempat gurumu, dan tidak tersenyum ketika terjadi pembicaraan; h) Tidak menoleh ke kiri dan ke kanan ketika berada di depan gurunya, tapi duduk dengan menundukkan mata, diam, sopan, dan tidak menggerakkan badan, seolah-olah kamu sedang sholat; i) Tidak bertanya ketika pendidik tampak bosan dan bingung;

Selanjutnya j) Berdiri ketika pendidik berdiri untuk menghormatinya; k) Tidak menguntit pendidik ketika keluar majelis untuk mengajak bicara dan bertanya; 1) Tidak bertanya kepada pendidik di jalan, tapi harus menunggu pendidik sampai di rumahnya atau sampai tempat peristirahatannya; dan m) Tidak berburuk sangka terhadap perbuatan pendidik yang secara lahiriah, menurut pandanganmu tidak diridhoi oleh Allah, karena pendidik itu lebih mengetahui rahasia-rahasia perbuatannya sendiri. ${ }^{31}$

\section{Konstruksi Pendidikan Islam Humanistik Dalam Pemikiran Syekh Nawawi Al-Bantani}

${ }^{31}$ Maragustam, Pemikiran Pendidikan Syekh Nawawi Al-Bantani..., hlm. 229-230. 
Para ahli humanistik melihat adanya dua bagian pada proses belajar yaitu: proses pemerolehan informasi baru dan personalisasi informasi ini pada individu. ${ }^{32}$ Pendidikan Islam Humanistik merupakan konsep belajar yang lebih melihat pada sisi perkembangan kepribadian manusia. Konsep ini berfokus pada potensi manusia untuk mencari dan menemukan kemampuan yang mereka punya dan mengembangkan kemampuan tersebut. Teori humanisme ini cocok untuk diterapkan dalam Pendidikan Islam karena memang teori pendidikan ini relevan dengan materi-materi pembelajaran yang bersifat pembentukan kepribadian, hati nurani, perubahan sikap, dan analisis terhadap fenomena sosial.

Konstruksi Pendidikan Islam Humanistik dalam pemikiran Syekh Nawawi Al-Bantani dapat dilakukan dalam beberapa komponen pendidikan yang menjadi obyek pemikiran Syekh Nawawi Al-Bantani, sebagai barikut;

\section{Hakikat Pendidikan dan Pengajaran dalam Islam}

Pengkajian makna hakikat pendidikan dan pengajaran dalam perspektif pendidikan humanistik harus dikaji dengan pendekatan filosofis. Maslow yang sebelumnya banyak belajar dari pemikiran Sigmund Freud dan John B. Watson pada gilirannya memperkenalkan sebuah metode psikologi yang dinamai psikologi madzhab ketiga atau dikenal dengan

32 Sukardjo dan Ukim Komarudin, Landasan Pendidikan, Konsep dan Aplikasinya, (Jakarta: PT. Raja Grafindo Persada, 2009), 63. 
sebutan psikologi humanistik (psychology of being). Konsep psikologi ini juga yang melatarbelakangi munculnya pendidikan Humanistik. Konsep ini merupakan sebuah upaya untuk mengembangkan suatu pendekatan psikologi baru yang lebih positif mengenai manusia, nilai-nilai tertinggi, cita-cita, pertumbuhan dan aktualisasi potensi manusia.

Bertumpu dari konsep Maslow tersebut, maka hakikat pendidikan dan pengajaran yang dikemukakan oleh Syekh Nawawi akan relevan dengan pendidikan Humanistik jika makna pendidikan dan pengajaran juga menyentuh aspek humanis atau kemanusiaan peserta didik. Syekh Nawawi dalam mengkaji mengenai hakikat pendidikan dan pengajaran bertumpu pada penafsiran Al-Qur'an yang menjelaskan mengenai makna $t a^{\prime} l i m$, tarbiyah, dan $t a^{\prime} d i b$.

Berdasarkan penafsiran kata yatsluu yang artinya membacakan dalam ayat ini, maka Syekh Nawawi menekankan bahwa arti kata tersebut bukan hanya sebatas membacakan saja, akan tetapi membacakan dengan mengarahkan manusia kepada iman. Adapun kata yu'allimu yang bermakna mengajarkan, menurut Syekh Nawawi memberikan makna yang lebih luas, yaitu mengajarkan dan memahamkan nilai-nilai dari ajaran tersebut serta bagaimana mengimplementasikan ajaran tersebut dalam kehidupan sehari-hari. Syekh Nawawi juga menjelaskan makna $t a^{\prime} d i b$ yang 
disamakan dengan ta'lim, meskipun $t a^{\prime} d i b$ lebih ditekankan kepada pembentukan Akhlak.

Konsep pendidikan dan pengajaran yang dimaknai oleh Syekh Nawawi sebagai upaya mengarahkan nilai-nilai untuk diimplementasikan dalam kehidupan sehari-hari peserta didik merupakan konsep yang relevan dengan pendidikan humanistik yang didalamnya juga memberlakukan psikologi humanistik. Relevansi kedua konsep ini antara lain berada pada penekanan pendidikan dan pengajaran sebagai upaya mengaktualisasikan potensi manusia.

Konstruksi pendidikan humanistik dalam pemikiran Pendidikan Syekh Nawawi berarti harus menekankan pada pengembangan potensi serta nilai-nilai moral dan agama pada peserta didik. Pendidikan harus dilaksanakan sesuai dengan kebutuhan peserta didik dalam mengembangakan potensi dan cita-citanya.

\section{Tujuan Pendidikan Islam}

Pendidikan humanistik bermaksud membentuk insan manusia yang memiliki komitmen humaniter sajati, yaitu insan manusia yang memiliki kesadaran, kebebasan, dan tanggung jawab sebagai insan manusia individual, namun tidak terangkat dari kebenaran faktualnya bahwa dirinya hidup di tengah masyarakat.

Syekh Nawawi menjelaskan bahwa tujuan Pendidikan Islam merupakan sebuah refleksi dari fungsi manusia untuk 
beribadah kepada Allah SWT dan menjadi khalifah di muka bumi. Selain itu Syekh Nawawi merincikan tujuan utama ini ke dalam empat tujuan nyata yang harus dicapai Pendidikan Islam.

Konsep tujuan Pendidikan Islam Humanistik dan konsep tujuan Pendidikan Islam Syekh Nawawi sangat relevan. Keduanya sama-sama mengedepankan semua aspek psikis maupun fisik peserta didik dalam proses pendidikannya. Pengembangan psikis dan fisik peserta didik ini sama-sama diorientasikan untuk bisa hidup menyesuaikan diri dengan lingkungan masyarakat.

\section{Metode Pendidikan Islam}

Metode Pendidikan Islam yang dikembangkan dalam konsep Pendidikan Humanistik harus sesuai dengan paradigma Humanisme yang bependapat; pertama, perilaku manusia itu dipertimbangkan oleh multiple intelligence. Bukan hanya kecerdasan intelektual semata, tetapi juga kecerdasan emosional dan spiritual. Dua kecerdasan terakhir ini tidak kalah pentingnya dalam menentukan keberhasilan hidup peserta didik.

Kedua, anak didik adalah makhluk yang berkarakter dan berkebribadian serta aktif dan dinamis dalam perkembangannya, bukan benda yang pasif dan yang hanya mampu mereaksi atau merespon faktor eksternal. Ia memiliki potensi bawaan yang penting. Karena itu pendidikan bukan 
membentuk anak didik sesuai dengan keinginan guru, orang tua atau masyarakat, melainkan pembentukan kepribadian dan self concept. Kepribadian dan self concept itulah yang paling memegang peran penting.

Ketiga, berbeda dengan behaviorisme yang lebih menekankan to have dalam orientasi pendidikannya, humanisme justru menekankan to be dan aktualisasi diri. Biarlah anak didik menjadi dirinya sendiri, peran pendidikan adalah menciptakan kondisi yang terbaik melalui motivasi, pengilhaman, pencernaan, dan pemberdayaan. Keempat, pembelajaran harus terpusat pada diri siswa (student centered learning). Siswalah yang aktif, yang mengalami dan yang paling merasakan adanya pembelajaran. Bukan semata-mata guru yang mengajar, yang memberikan stimulus atau yang beraktualisasi diri. $^{33}$

Berdasarkan pada orientasi metode Pendidikan Islam Humanistik tersebut, maka pengkajian mengenai relevansinya dengan pemikiran Syekh Nawawi dapat dilakukan. Syekh Nawawi menjelaskan bahwa ada delapan prinsip yang harus menjadi patokan dalam menerapkan metode pendidikan Islam. Kedelapan prinsip tersebut sudah sangat relevan dengan konsep orientasi metode Pendidikan Islam Humanistik. Keduanya sama-sama memaparkan bahwa metode Pendidikan

33 Tobroni, Pendidikan Islam: Paradigma Teologis, Filosofis dan Spiritualitas, (Malang: UMM Press, 2008), 122 
Islam harus mampu memposisikan peserta didik sebagai subyek, menyentuh aspek nilai kemanusiaan, serta memberikan ruang untuk mengembangkan potensi yang dimilki peserta didik.

\section{Pendidik dan Peserta Didik}

Manusia adalah subjek pendidikan, dan sekaligus pula sebagai objek pendidikan. Sebagai subjek pendidikan, manusia (pendidik) bertanggung jawab dalam menyelenggarakan pendidikan. Secara moral berkewajiban atas perkembangan pribadi anak-anak mereka atau generasi penerus. Manusia dewasa yang berfungsi sebagai pendidik bertanggung jawab untuk melaksanakan misi pendidikan sesuai dengan tujuan dan nilai-nilai yang dikehendaki manusia di mana pendidikan berlangsung.

Sebagai objek pendidikan, manusia (peserta didik) merupakan sasaran pembinaan dalam melaksanakan (proses) pendidikan, yang pada hakikatnya ia memiliki pribadi yang sama dengan manusia dewasa, namun karena kodratnya belum berkembang. ${ }^{34}$

Pandangan mengenai pendidik sebagai subyek pendidikan dan peserta didik sebagai obyek pendidikan tentunya tidak relevan dengan teori pendidikan Humanistik. Pendidikan Humanistik memandang bahwa baik pendidik dan

34 Uyoh Sadullah, Pengantar Filsafat Pendidikan, (Bandung: Alfabeta, 2007), 79. 
peserta didik kesemuanya harus berfungsi sebagai obyek dan subyek pendidikan. Sebagai subyek pendidikan, peserta didik harus diposisikan sebagai manusia aktif yang memiliki kemampuan mengembangkan potensinya.

Pendidikan yang humanistik memandang manusia sebagai manusia, yakni makhluk hidup ciptaan Tuhan dengan fitrah-fitrah tertentu. Sebagai makhluk hidup, ia harus melangsungkan, mempertahankan, dan mengembangkan hidupnya. Pendidikan humanistik adalah pendidikan yang mampu memperkenalkan apresiasinya yang tinggi kepada manusia sebagai makhluk Allah yang mulia dan bebas serta dalam batas-batas eksistensinya yang hakiki, dan juga sebagai pemimpin di bumi.

Syeikh Nawawi mengajukan tujuh belas syarat sebagai pendidik dan empat belas syarat sebagai peserta didik. Berdasarkan syarat yang diajukan Syekh Nawawi memang harus diakui bahwa ada perlakuan yang kurang humanis kepada peserta didik. Pendidik dalam ketujuh belas syarat tersebut menjadi pihak yang ordinate atau pokok serta mendominasi proses pendidikan Islam. Adapun siswa diposisikan sebagai subordinate yang menjadi bagian kedua dari proses pendidikan, sehingga banyak diposisikan pasif.

Pendapat syekh Nawawi mengenai syarat pendidik dan peserta didik dalam pendidikan Islam tersbeut memang dianalisis menggunakan konsep pendidikan Humanistik, maka 
saat ini kurang relevan. Meskipun demikian, ada konsep humanis yang tersirat dalam pemikiran Syekh Nawawi mengenai pendidik dan peserta didik. Pendidik yang harus bisa menjadi teladan dan peserta didik yang harus menjaga penghormatannya terhadap pendidik menjadi konsep yang relevan dengan pendidikan Humanistik

Hal ini menjadi relevan karena baik konsep pemikiran Syekh Nawawi dan konsep pendidikan Humanistik mengenai pendidik dan peserta didik sama-sama mengedepankan aspek humanis atau manusiawi dalam menjalin hubungan diantara keduanya.

\section{E. Ucapan Penutup}

Rekonstruksi Pendidikan Islam Humanistik dalam pemikiran Syekh Nawawi Al-Bantani dilakukan pada empat komponen pendidikan. Tiga komponen pendidikan menurut pendapat pemikiran Syekh Nawawi Al-Bantani relevan atau sesuai dengan konsep Pendidikan Islam Humanistik, adapun ada satu komponen pendidikan menurut pemikiran Syekh Nawawi yang kurang relevan dengan konsep Pendidikan Islam Humanistik. Tiga komponen yang relevan tersebut antara lain; hakikat pendidikan dan pengajaran Islam, tujuan pendidikan Islam, serta metode pendidikan Islam. Adapun satu komponen pendidikan Islam menurut pemikiran Syekh Nawawi yang kkurang relevan yaitu mengenai pendidik dan peserta didik 
dengan tujuh belas syarat sebagai pendidik dan empat belas syarat sebagai peserta didik yang diajukan oleh Syekh Nawawi. 


\section{DAFTAR PUSTAKA}

Eko Susilo, Dasar-Dasar Pendidikan, cet. 3, (Semarang: Effhar, 2001).

Imam Machali, Pendidikan Islam \& Tantangan Globalisasi (Yogyakarta: Ar-Ruzz Media, 2004).

Maragustam, Pemikiran Pendidikan Syekh Nawawi Al-Bantani, (Yogyakarta: Datamedia, 2007).

Mudjia Rahardjo, "Menuju Pendidikan Humanistik yang Berwawasan Pembangunan", Majalah Tarbiyah No. 35, (Tahun XII, JuliSeptember 1994).

Muhammad Ulul Fahmi, Ulama Besar Indonesia Biografi dan Karyanya, (Kendal: Amanah Grafika, 2008).

Muhammad 'Atthiyyah AL-Abrasyi, Prinsip-prinsip dasar Pendidikan Islam (Bandung: Pustaka Setia, 2003).

Paulo Friere, Pendidikan Kaum Tertindas (Jakarta: LP3ES, 1991).

Syekh Muhammad Nawawi, Murah Labayd (Mesir: Darul Ihya'AlKutb Al-'Arabiyah, Tanpa Tahun).

Sudirman Tebba, Mengenalkan Wajah Islam Yang Ramah (Banten: Pustaka Irvan, 2007).

Sukardjo dan Ukim Komarudin, Landasan Pendidikan, Konsep dan Aplikasinya, (Jakarta: PT. Raja Grafindo Persada, 2009).

Tobroni, Pendidikan Islam: Paradigma Teologis, Filosofis dan Spiritualitas, (Malang: UMM Press, 2008).

Uyoh Sadullah, Pengantar Filsafat Pendidikan, (Bandung: Alfabeta, 2007). 
Menggagas Pendidikan Islam Humanistik Perspektif Pemikiran Syekh Nawawi Al-Bantani

232 | AT-TUROTS: Jurnal Pendidikan Islam 